\title{
How can principal leadership practices promote teacher collaboration and organizational change? A longitudinal multiple case study of three school improvement initiatives
}

\author{
André Meyer ${ }^{1}\left(\mathbb{D} \cdot\right.$ Viola Hartung-Beck $^{2} \cdot$ Anna Gronostaj $^{3} \cdot$ Sophie Krüger ${ }^{1}$. \\ Dirk Richter ${ }^{1}$
}

Accepted: 10 January 2022

(c) The Author(s) 2022, corrected publication 2022

Schools must regularly examine and adapt established practices to address students' and teachers' changing needs (academic, social, emotional, and occupational; Askell-Williams \& Koh, 2020). Yet many of the innovations developed to meet these needs fail due to a lack of strategies for implementation (e.g., consistent goal setting), structural prerequisites (e.g., time for planning and implementing innovations), and motivation of school staff (e.g., innovativeness; Cheng \& Walker, 2008; Palumbo \& Manna, 2019). Theories of organizational change in the school context posit that principals and teachers act as change agents, innovating organizational practices, building collective knowledge around change, and supporting a positive climate for innovations. For this reason, we first assume that teacher collaboration is a key element for organizational change. When teachers collaborate to improve their schools, they can collectively identify the school's needs, develop targeted and effective innovations, and, ultimately, implement innovations. Second, we assume principal leadership is a key supporting factor in teacher collaboration, as principals can ensure that teachers have sufficient time and resources, support in the creation of teacher teams, guide these teams on the process level (e.g., goal-setting), and motivate teachers to achieve the desired organizational changes. Empirical evidence supports this assumption and suggests that principals can involve teachers in decision making relating to the planning and implementation of innovations and can create a caring environment for teachers to change their practices (Fix et al., 2020; Seashore

André Meyer

andre.meyer@uni-potsdam.de

1 Department of Educational Sciences, University of Potsdam, Karl-Liebknecht-Str. 24/25, 14476 Potsdam, Germany

2 Faculty of Applied Social Sciences, University of Applied Sciences and Arts Dortmund, Dortmund, Germany

3 Robert Bosch Stiftung GmbH, Stuttgart, Germany 
Louis \& Murphy, 2017). However, there has been little in-depth research to date on the mechanisms that foster teachers' and principals' collaboration to achieve organizational change. In particular, previous empirical research has not fully investigated the process from planning to implementation of improvement initiatives (Palumbo \& Manna, 2019). As sustainable innovations can cover time spans of several years, longitudinal insights are urgently needed.

Using a longitudinal data set from three waves of interviews with principals and teachers at three schools in Germany, the present study addresses the aforementioned research gap by investigating the role of principals as initiators of teacher collaboration and organizational change in schools. The data were collected in a research project that studied the implementation of a school improvement initiative over the course of two years. In the following sections, we provide definitions, theoretical rationales, and empirical evidence around the concept of organizational change, teachers as change agents, and principals as facilitators of teacher collaboration for organizational change.

\section{Theoretical framework of organizational learning and organizational change}

Organizational learning in schools involves the capacity of teachers, principals, and members of leadership teams to collectively detect problems in established practices, find appropriate solutions, and implement innovations (Seashore Louis \& Murphy, 2017; Silins et al., 2002). The implementation of innovations in schools is usually referred to as school improvement. School improvement initiatives may focus on innovations at the organizational level (e.g., defining academic and pedagogical goals), the staff level (e.g., professional development of teachers, staff appraisals), or the classroom level (e.g., evaluation and revision of curricula, implementation of innovative classroom practices; Muckenthaler et al., 2020). Numerous empirical studies have contributed to the definition and operationalization of organizational learning (e.g., Askell-Williams \& Koh, 2020; Day et al., 2016; Schechter, 2008; Seashore Louis \& Lee, 2016; Silins et al., 2002). The present study draws on a six-dimensional framework to analyze the capacity of organizational learning as suggested by Marks and Seashore Louis (1999) that has been subjected to critical review and empirical analysis in more recent studies (e.g., Feldhoff, 2011).

The six dimensions of organizational learning are as follows. First, schools as learning organizations have a structure that allows teachers to meet regularly, exchange information, and collaborate (e.g., teacher teams on a subject or grade level). Second, to ensure that change processes are sustainable, teaching staff need to share a commitment to school improvement: Here, teacher collaboration catalyzes the sharing and processing of information about common visions and goals (Seashore Louis \& Lee, 2016). Third, principals and leadership teams need to provide teachers with opportunities for participation in decision making processes so that teachers have a voice and feel empowered (Austin \& Harkins, 2008; Morris et al., 2020). Fourth, organizational learning requires knowledge and skills that members of the school community or other individuals (e.g., principals, teachers, or external experts) 
either bring with them or acquire through training or other learning opportunities. Fifth, school leadership plays a decisive role in ensuring that all these resources are available. Principals need to set clear goals for school improvement, support teachers in achieving these goals, and distribute leadership practices (e.g., decision making) on different levels of the school structure (Sun \& Leithwood, 2015). Sixth, schools need to create an internal culture of accountability by setting distinct standards for school improvement that help school staff adjust to organizational changes and feel invested in reaching the school's goals.

Of the aforementioned six dimensions of organizational learning, the dimensions of principal leadership, teacher collaboration, and teacher participation play an especially important role in organizational change. We assume that specific leadership practices can enable principals to support teacher collaboration and participation of teachers. In this way, principals might act as facilitators for meaningful and collectively implemented processes of organizational change at the micro level of teaching, the meso level of collaboration, and the macro level of school improvement. For this reason, the present study investigates the role of principals and teachers as change agents for organizational learning in schools. We sought to contribute to the current body of research by applying the framework offered by Marks and Seashore Louis (1999) to the process of organizational change in three schools using a comparative case study approach (Yin, 2014).

\section{Teachers as change agents for organizational change}

Empirical studies have shown that teachers, principals, and other members of school leadership teams can function as change agents and shape organizational learning in schools (Palumbo \& Manna, 2019). In the following sections, we will present theoretical rationales and empirical insights that demonstrate diverse ways in which teachers and principals can serve as change agents.

Marks \& Seashore Louis (1999) suggested that organizational change requires knowledge, skills, and a shared commitment by teaching staff. We assume teacher collaboration to be an important prerequisite for organizational change, as teachers can reflect upon established practices, identify potential areas of school improvement, and plan strategies for change (Kelchtermans, 2006; Leonard \& Leonard 1999). Teacher collaboration can take place in teacher teams of different types, such as teams created for the specific purpose of organizational change, teams that teach the same subject or grade level, as well as loose networks of teachers. We differentiate between low-cost and high-cost forms of teacher collaboration (Muckenthaler et al., 2020). While lowcost collaboration involves teachers exchanging information and experiences, highcost collaboration entails teachers sharing workloads and working together toward their group's goals (Gräsel et al., 2006). Moreover, interactions between teachers may increase the entire teaching staff's motivation to participate in organizational innovations, as teachers who are directly involved in change processes can convey the usefulness of specific innovations to others. This promotes teachers' sensemaking of innovations and creates positive expectations of the costs and benefits of organizational change (Palumbo \& Manna, 2019; Weick, 1995). 
Empirical evidence suggests that teacher collaboration is one of the most important factors of change in schools (Askell-Williams \& Koh, 2020; Day et al., 2016). In their literature review on the supporting factors of organizational change, Palumbo and Manna (2019) concluded that teacher teams that are created for the sole purpose of innovating organizational practices can support change processes. Nguyen and $\mathrm{Ng}$ (2020) as well as Fix et al., (2020) found that teams of teachers (and members of the school leadership team) support sensemaking of innovations, as teachers can collectively reflect on established practices, find ideas for innovations, create goals and strategies, evaluate ideas with colleagues, and build task groups to involve further teachers in decision making processes. Seashore Louis and Lee (2016) report that teachers who observe each other in the classroom and collectively reflect on instructional practices report higher levels of practices that are conducive to organizational learning. The authors argued that teacher collaboration needs to be more than an exchange of information with peers in order to be effective for organizational innovations. Instead, effective implementation of innovations requires teachers to collectively share ownership of change, exchange in-depth information on organizational practices, and receive meaningful feedback on instructional behavior.

In conclusion, past research has provided evidence that teacher collaboration is an important prerequisite for organizational change - especially when teacher teams are created to implement innovations. We assume that principals can support teacher collaboration and, hence, foster processes of organizational change. In the following, we explain theoretical rationales on the relationship between principal leadership, teacher collaboration, and organizational change.

\section{Principals as facilitators of teacher collaboration for organizational change}

Organizational change in schools requires collective sensemaking by the teaching staff (i.e., shared knowledge, norms, and values related to the innovation) in order to appear plausible and win approval from teachers (Ala-Laurinaho et al., 2017; Thurlow \& Mills, 2014). Principals can support sensemaking in schools in two ways. First, principals can involve teachers in decision-making processes and share responsibilities for change processes (Rikkerink et al., 2015). This gives teachers a voice and creates accountability and a positive climate conducive to change. Second, as sensemaking derives from social interactions between teachers, principals can support teacher collaboration to provide opportunities for interacting (Ala-Laurinaho et al., 2017; Weick 1995). Empirical research suggests that teachers who collaboratively participate in school improvement (i.e., in decision making and implementing innovations) are more committed to organizational change and, in turn, support a sustainable implementation of changes (Palumbo \& Manna, 2019; Rikkerink et al., 2015).

We assume that principals can support teacher collaboration for organizational change on different levels. On a structural level, principals can support teachers in establishing teacher teams by moderating teacher conferences or similar staff meetings (Seashore Louis \& Murphy, 2017). As principals are responsible for schedul- 
ing teachers' class times, they can allocate time slots for teachers to collaborate on organizational innovations. Silins and Mulford (2004) studied schools as learning organizations and found evidence that these schools implemented structures (e.g., teacher committees or teams) that "encourage staff to participate in all aspects of the schools' functioning, including decision making and review" (p. 459). These structures provided teaching staff the opportunity to take the initiative and share a sense of direction.

Once initiatives have been implemented, principals can also guide teacher teams on the process level of organizational change. On the one hand, they can define a clear mission and set precise goals for innovations themselves (Leithwood et al., 2019; Truijen et al., 2013). On the other hand, principals can involve teachers in the process of goal setting. Results from Amels et al., (2020) suggest that teachers who are involved in decision making around innovations are more likely to internalize organizational goals as personal goals. When teacher teams perceive their goals to be self-initiated, they are more likely to develop collective ownership and sustainably pursue these goals (Nguyen \& Ng, 2020; Thurlow \& Mills, 2014).

Drawing on expectancy-value theory (Wigfield \& Cambria, 2010; Wigfield \& Eccles, 2000), we assume that teachers are motivated to contribute to change processes when they expect the desired innovations to be of high relevance for the overall school community and their individual professional practices. In this regard, principals can support teachers on the motivational level by involving them in finding ideas for innovations. This gives teachers a voice and provides a bottom-up structure for pinpointing areas of organizational change, which in turn enhances teachers' acceptance and willingness to participate in change processes (Marks \& Seashore Louis, 1999). Results from Bartunek et al. (2006) suggest that motivated staff are less resistant to change processes and more willing to actively participate in the implementation of organizational innovations. Klein and Bremm (2019) report that a supportive relationship between principals and teachers (e.g., teacher empower-

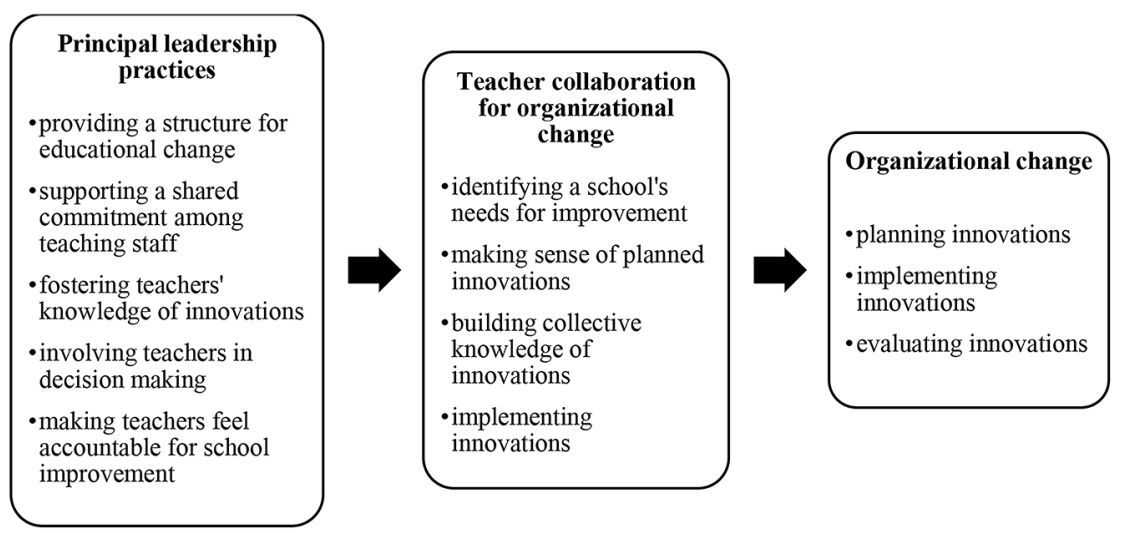

Fig. 1 Conceptual framework of the present study 
ment, attentiveness toward teachers, a school culture that allows mistakes) may also contribute to teachers' engagement in change processes in schools. Evidence from Lee et al. (2021) indicates that teachers who report high levels of teacher participation in school improvement also report high degrees of openness and consensus in the target-setting process of innovations. However, when teachers expect high costs to result from the innovation (e.g., additional workload), they may resist being part of the change process (Bartunek et al., 2006; Fix et al., 2020). When teachers raise doubts about innovations, principals can address their questions and concerns and react appropriately to reduce resistance (Gilley et al., 2009; Wigfield \& Eccles, 2000).

In sum, empirical evidence suggests teacher collaboration to be an important factor for organizational change in schools. We assume that principal leadership can function as a catalyst for teacher collaboration as principals can help teachers to initiate teams, guide collaborative processes, and motivate teacher teams to engage actively in change processes (Meyer, Richter \& Hartung-Beck, 2020; see Fig. 1). Previous research has investigated the relationship between teacher collaboration and organizational change, but most of this research has failed to take the role of principal leadership into consideration. For this reason, we need in-depth insights based on qualitative research that goes beyond the description of structures and procedures and takes into account mechanisms, triggers, and barriers of organizational change (Palumbo \& Manna, 2019). In addition, we need to investigate social relationships and motivational aspects of school staff in the context of organizational change as these have largely been neglected in previous research (Klein \& Bremm, 2019). As processes of organizational change usually take place over long periods of time, comprehensive longitudinal data on the entire process, from planning to implementing innovations, are required to provide meaningful insights. Qualitative research based on longitudinal data sources is rare, however, due to the high costs, effort, and resources required (e.g., Rikkerink et al., 2015).

The present study contributes to narrowing this gap in the research, as it uses longitudinal data from three waves of interviews (14 months) with principals, members of school leadership teams (e.g., vice principals), and teachers from three schools in Germany. The study was conducted as part of an evaluation of a two-year professional development (PD) program that supported the development and implementation of a school improvement initiative in each participating school. The participants in the PD program chose different projects (e.g., revising the concept of students' self-organized learning) that were initiated and implemented in their schools. We investigated the following research question: How can principals facilitate teacher collaboration to promote organizational change?

\section{Methods}

\section{Study design}

We conducted 50 semi-structured interviews (Adams, 2015; Longhurst, 2003) with a mean duration of $30.81 \mathrm{~min}(S D=11.06)$. The PD program started in September 2017 and the first wave of interviews took place in March 2018 (T1). Interviews were 
conducted at T2 in November 2018 and at T3 in May 2019. 38 interviews were conducted as individual interviews and 12 as focus groups. All participants were asked for permission for data collection and data use. Participants were assured that all data would remain anonymous.

\section{Sample}

The sample for our study consisted of principals and one member of their leadership team who both participated in the PD and volunteered for the interview study. In addition, we interviewed further members of school leadership teams, teachers who held a specific position in the school (e.g., heads of subject departments), and teachers without any additional responsibilities (see Table 1). The numbers of participants differed between schools due to differing school sizes (see Table 2). The longitudinally varying number of participants (in particular at the school Oslo) was due to smaller focus groups at T2 and T3.

All of the schools in the present sample were secondary schools. In Germany, secondary schools differ with regard to the potential career outcomes of students. While secondary schools with an academic track prepare students to attend university (Gymnasium), secondary schools without an academic track prepare students to attend vocational schools (Gemeinschaftsschule). Some of these non-academic-track secondary schools offer an optional academic track for high-achieving students. The sample in our study consisted of one academic-track secondary school (the school Oslo ${ }^{1}$ ) and two secondary schools without an academic track (the schools Tokyo and Cape Town). The schools Tokyo and Cape Town were relatively small in terms of the number of students and teachers. Cape Town, however, had a higher proportion of students with a low socioeconomic status (SES), who therefore received free instructional materials, and students with a migration background (see Table 2). The school Oslo had a high number of students and teachers and a relatively small proportion of low-SES students, students with special needs, and students with a migration background.

Table 1 Number of participants by school

\begin{tabular}{lllr}
\hline & Tokyo & Cape Town & Oslo \\
\hline T1: $N_{\text {Participants }}$ & & & \\
$\quad$ Leadership team & 3 & 2 & 9 \\
Teachers & 3 & 7 & 12 \\
T2: $N_{\text {Participants }}$ & & & \\
$\quad$ Leadership team & 3 & 3 & 5 \\
$\quad$ Teachers & 3 & 4 & 9 \\
T3: $N_{\text {Participants }}$ & & & 5 \\
Leadership team & 3 & 2 & 6 \\
$\quad$ Teachers & 3 & 3 & \\
\hline
\end{tabular}

${ }^{1}$ For reasons of anonymity, we assigned fictional names to the schools. 
Table 2 Case description

Note. Information on the percentages of specialneeds students, students with migration background, and low-SES students was obtained from the principals; information on the percentage of low-SES students was based on students receiving financial support for school supplies

\begin{tabular}{|c|c|c|c|}
\hline & Tokyo & Cape Town & Oslo \\
\hline School track & $\begin{array}{l}\text { Secondary } \\
\text { school w/ } \\
\text { optional } \\
\text { academic } \\
\text { track } \\
\text { (grades } \\
5-10, \text { or } \\
5-13 \text { ) }\end{array}$ & $\begin{array}{l}\text { Secondary } \\
\text { school w/o aca- } \\
\text { demic track } \\
\text { (grades 5-10) }\end{array}$ & $\begin{array}{l}\text { Secondary } \\
\text { school w/aca- } \\
\text { demic track } \\
\text { (grades 5-12) }\end{array}$ \\
\hline$N_{\text {Teachers }}$ & 34 & 33 & 90 \\
\hline$N_{\text {Students }}$ & 375 & 374 & 960 \\
\hline $\begin{array}{l}\text { Percentage of } \\
\text { special-needs } \\
\text { students }\end{array}$ & 21 & $\mathrm{n} / \mathrm{s}$ & 4 \\
\hline $\begin{array}{l}\text { Percentage of stu- } \\
\text { dents with a migra- } \\
\text { tion background }\end{array}$ & 18 & 50 & 9 \\
\hline $\begin{array}{l}\text { Percentage of low- } \\
\text { SES students }\end{array}$ & 34 & 54 & 2 \\
\hline $\begin{array}{l}\text { School Improve- } \\
\text { ment Initiative }\end{array}$ & $\begin{array}{l}\text { Transfor- } \\
\text { mation } \\
\text { into an } \\
\text { all-day } \\
\text { school }\end{array}$ & $\begin{array}{l}\text { Revision of the } \\
\text { school's concept } \\
\text { of students' } \\
\text { self-organized } \\
\text { learning } \\
\text { Revision of the } \\
\text { instructional } \\
\text { schedule }\end{array}$ & $\begin{array}{l}\text { Creating a } \\
\text { school concept } \\
\text { for PD } \\
\text { Classroom } \\
\text { disruptions } \\
\text { Refurbishing } \\
\text { the staff room } \\
\text { Refurbishing } \\
\text { the classroom } \\
\text { for biology } \\
\text { Collaboration } \\
\text { of teachers in } \\
\text { STEM subjects }\end{array}$ \\
\hline
\end{tabular}

\section{Data collection and analysis}

For addressing the research question, we used the same list of open-ended questions for all participants, as we intended to gain comprehensive insights from the perspectives of both school leadership and the teaching faculty (see Table 3 for examples). In particular, we asked all participants at different time points to describe the phases of planning and implementing their innovation and who was involved in these processes. Especially at T2 and T3, we asked all participants to assess the outcomes of their innovation and whether they wished they had had more participation and collaboration from teachers.

With regard to data analysis, we followed the guidelines provided in the approach of Structuring Content Analysis, and used deductive and inductive category formation. We went through the following four phases using the software MAXQDA 2020 (Muslic, Gisske \& Hartung-Beck, 2020; Kuckartz, 2018; Mayring, 2003).

Phase 1 We derived deductive categories from a literature review in the fields of organizational change, principal leadership, and teacher collaboration. 
Table 3 Examples of guiding questions from semi-structured interviews

\begin{tabular}{|c|c|}
\hline List of themes & Guiding questions \\
\hline Planning the innovation & $\begin{array}{l}\text { Please describe your school's } \\
\text { planned innovation. What are } \\
\text { the main goals? }\end{array}$ \\
\hline Participation/collaboration & $\begin{array}{l}\text { Who is involved in its develop- } \\
\text { ment? Would you like more/less } \\
\text { participation from others? }\end{array}$ \\
\hline Communication & $\begin{array}{l}\text { To what extent are teachers } \\
\text { being informed about the inno- } \\
\text { vation? Do you think that teach- } \\
\text { ers feel sufficiently informed? }\end{array}$ \\
\hline Implementing the innovation & $\begin{array}{l}\text { What is the strategy for imple- } \\
\text { menting the innovation? }\end{array}$ \\
\hline Participation/collaboration & $\begin{array}{l}\text { To what extent are teachers } \\
\text { being involved in implementing } \\
\text { the innovation? Do you think } \\
\text { teachers would like more/less } \\
\text { participation? }\end{array}$ \\
\hline Conclusion/assessment & $\begin{array}{l}\text { How would you assess the } \\
\text { innovation so far? What went } \\
\text { well? What could be improved? }\end{array}$ \\
\hline
\end{tabular}

Phase 2 Two coders analyzed two interviews from the material to evaluate the fit of the coding scheme. We coded the material using complete sentences as the smallest coding unit. We allowed coding of complete sections in order to include contextual information for further analyses. Also, we allowed coding of particular sections of the material with multiple categories in order to detect categories that were not clearly defined. The two coders discussed disparities in their results and revised the coding scheme accordingly. Codes were added to the coding scheme if the coders agreed on missing codes that might fit the material. Also, codes were removed from the coding scheme if they did not fit the interview material, or merged if they could not be distinguished properly (e.g., involving teachers in planning processes and involving teachers in implementation processes became involving teachers in decision making).

Phase 3 The coders analyzed another four interviews from the material to evaluate the fit of the revised coding scheme following the guidelines for Phase 2. Again, the coders applied revisions to the coding scheme accordingly.

Phase 4 The coders analyzed the six interviews from Phase 2 and Phase 3 to evaluate the revised coding scheme with regard to its fit to the data using Cohen's $\kappa$ to determine inter-rater agreement. Following recommendations by Wirtz and Caspar (2002), we used a cut-off value of $\kappa>0.60$ to indicate a satisfactory inter-rater agreement. After achieving satisfactory inter-rater agreement for all interviews in the trial phase, we divided the remaining material between the two coders, who then analyzed the interviews using the final coding scheme (see Table 4 in the Appendix). As a final check, we used four randomly selected interviews from T3 to evaluate inter-rater agreement. Again, we achieved values of $\kappa>0.60$, which indicated satisfactory agreement (Fig. 2). 
Phase 1: Based on relevant empirical research, we created a coding scheme consisting of deductive categories. In phase 1 , we created definitions for deductive categories.

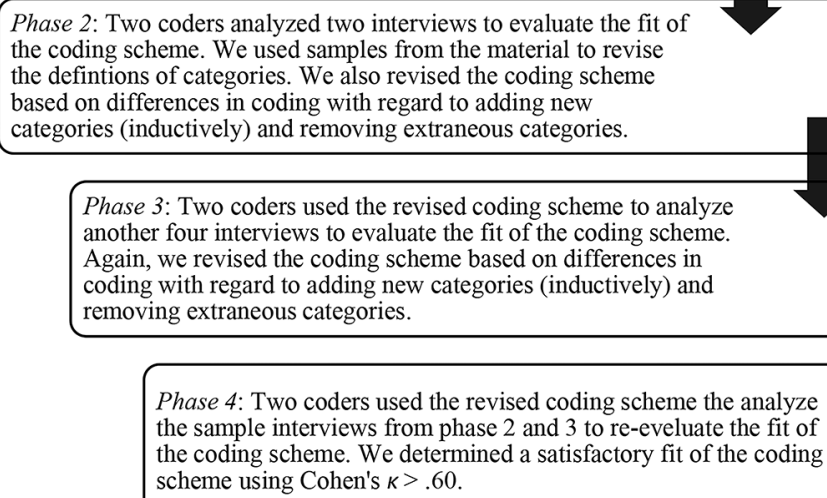

Phase 4: Two coders used the revised coding scheme the analyze the sample interviews from phase 2 and 3 to re-eveluate the fit of the coding scheme. We determined a satisfactory fit of the coding scheme using Cohen's $K>.60$.

Fig. 2 Sequence of steps of creating the coding scheme

The final coding scheme consisted of four broad themes that included several categories each: school structure, leadership, teachers' perceptions, and teacher collaboration.

(1) School structure: Following results from Marks and Seashore Louis (1999), we wanted to investigate whether schools implemented formal or informal groups of teacher teams in their organizational structure that might contribute to organizational change.

(2) Leadership: We investigated how leadership practices supported the development and implementation of innovations in the schools. These leadership practices included clear goal-setting (Leithwood \& Jantzi, 2005; Schechter, 2008), involving teachers in decision making (Marks \& Seashore Louis, 1999; Rikkerink et al., 2015), strategic communication of change processes (Feldhoff, 2011), providing teachers with autonomy (Fix et al., 2020), representing teachers' interests, and dealing with conflicts and resistance (both developed inductively based on the material).

(3) Teachers' perceptions: We investigated teachers' perceptions with regard to the innovation (knowledge related to the innovation, shared goals, perceived benefits and costs, discontent with the prior/current situation, resistance toward the innovation; Feldhoff 2011, Gray \& Summers, 2015; Marks \& Seashore Louis, 1999; Voelkel \& Chrispeels, 2017) and motivational aspects (collective efficacy, innovativeness of teaching staff; Gray \& Summers, 2015).

(4) Teacher collaboration: We also investigated whether teachers engaged in lowcost (i.e., exchanging information and material) or high-cost forms of teacher collaboration (i.e., shared workload, joint work; Gräsel et al., 2006). Moreover, 
we investigated whether schools implemented norms and standards for teacher collaboration (Hoy \& Sweetland, 2001) and whether teacher teams showed interdependence (Johnson \& Johnson, 2009).

With regard to data analysis, we used a case study approach to conduct within-case and cross-case analyses (Muslic, Gisske \& Hartung-Beck, 2020; Yin, 2014). We applied the coding scheme to the material and created case summaries for each school at each time point using a case-matrix design ${ }^{2}$ that included perspectives of all interviewees (Muslic, Gisske \& Hartung-Beck, 2020; Kuckartz, 2018). First, within-case analyses on the cross-sectional level allowed us to compare different perspectives within the hierarchical school structure (i.e., principal and teachers). This helped us to reduce subjectivity in reports of individual interviewees and gain more reliable insights. Second, within-case analyses on the longitudinal level allowed us to reconstruct the change process and identify factors that support and hinder organizational change. Third, cross-case analyses helped us to compare all three cases with regard to longitudinal changes while also considering contextual factors (e.g., school size, external support) for our interpretations. As a result, we identified several themes of principal leadership practices that might have affected teacher collaboration and, in turn, organizational change in these schools. We used the themes identified to develop specific assumptions, as presented in the discussion section.

\section{Findings}

In the following sections, we first present descriptive findings from within-case analyses that provide contextual information and insights on the change process in all three schools. We then present results from cross-case analyses on leadership practices that might have affected teacher collaboration and organizational change processes. We used italics to highlight the specific categories in our coding scheme and references to specific interviewees (for all categories, see Table 4 in the appendix). Detailed information on every case summary can be found as supplementary material in the online repository (i.e., case matrices).

As the present study investigates principals and teachers from Germany, we will briefly provide information on the German context for a better understanding of the results. Change-specific teacher teams known as steering groups have existed in Germany since the early 2000s (for an overview, see Feldhoff et al., 2010). Empirical research has shown that steering groups play an important role in organizational change in schools in Germany (Berkemeyer \& Holtappels, 2007). Steering groups take on responsibility for processes of organizational change, initiating innovations, guiding communication processes, and coordinating project management (Feldhoff et al., 2010). Members of steering groups may be elected by the teaching faculty and, if so, are mandated to take part in decision-making processes in collaboration with school principals. For this reason, steering groups are positioned between the principal and the teaching faculty and are responsible for coordinating communica-

\footnotetext{
${ }^{2}$ All case matrices can be found as supplementary material in the online repository.
} 
tion related to organizational change within the school's hierarchical structure (e.g., passing on information on recent innovations and upcoming tasks; Feldhoff et al., 2008; Feldhoff et al., 2010).

\section{Within-case analyses}

The school Tokyo: The innovation that Tokyo implemented focused on the organizational transformation into an all-day school (leadership - setting goals and developing strategies). Unlike half-day schools which students usually attend for around six hours a day, all-day schools in Germany extend the school day to around eight hours with additional extracurricular activities that consist of subject-related project groups, sports, and arts-related activities. To meet the needs of students and parents, the school Tokyo had been providing both options, allowing parents to choose whether their children would attend for part or all of the day. However, the leadership team saw increasing interest in all-day classes, which is why Tokyo switched to all-day classes only for grade 5 in the 2017/2018 school year. As the principal and leadership team expected increased interest in all-day classes, they set the long-term goal of transforming their school into an all-day school. However, this innovation required a vote from the larger school community (i.e., teaching faculty, students, parents) in order to be legally binding (leadership-setting goals and developing strategies). The idea had been put up for a vote in the past, but a majority of teachers had voted against the innovation. The leadership team assumed that the composition of the teaching staff had changed (i.e., lower mean age and higher innovativeness of teachers) and now expected a vote in favor of the innovation. They intended to carefully prepare for the vote by establishing teacher teams for the specific purpose of organizational change (teacher collaboration-joint work), involving teachers in decision making processes (leadership), emphasizing the innovation's benefits, and discussing questions and doubts related to the innovation (leadership-dealing with conflicts and resistance).

"[...] our vision is that our school will become an all-day school. And the three of us think that it is only possible to be a good school as an all-day school. We failed in the past because the teaching staff voted against the idea of an all-day school. The staff was different back then-we had some people who didn't share our vision, let's put it that way. It was very close, but still. And then we said: 'Ok, let's do it again. We'll put it on our agenda. We'll work on the concept and try to implement an outstanding innovation because it's important to us. ,", (principal, Tokyo, T1).

The leadership team created a steering group as well as project-specific groups that worked on different areas of the change process (leadership-involving teachers in decision making, teacher collaboration-shared workload, joint work). The steering group was supposed to coordinate the procedures as part of the change process (e.g., organizing conferences). As they reported having met regularly at T1, the steering group met less frequently throughout our study, so their work was hardly visible to any of the teachers at T2 and T3 (teacher collaboration-quantity of teacher 
collaboration). Members of the steering group reported that this was due to a high workload and lack of time. Furthermore, project-specific groups were initiated at T1 to support the implementation of the innovation (leadership - involving teachers in decision making). These groups were supposed to work collaboratively on different aspects of the project and consisted of teachers who volunteered to take part (teacher collaboration-shared workload, joint work). Again, throughout our study, relatively few interviewees appeared to know about the work of the project-specific groups. At T3, only the principal was able to report on one particular project-specific group that worked on the implementation of the innovation and had become an established part of the change process.

"No. It hasn't taken place for a long time now, because every Friday we were busy with class conferences, where the principal is also involved, so even our last scheduled meeting did not work out. I would need to look in my calendar to see when the last meeting took place. [...] We're not active right now, I have to admit [...]." (teacher, member of the steering group, Tokyo, T3).

As the teaching faculty raised concerns and questions about the innovation, the principal instructed the staff council ${ }^{3}$ to visit other all-day schools in the district to gather information on their staff's experiences with the all-day concept (leadership - dealing with conflicts and resistance; teacher, T1). The staff council was then supposed to discuss insights with the teaching staff to answer questions and resolve uncertainties. Somewhat before T2, the staff council presented insights from their school visits to the teaching faculty. Over the course of our study, the leadership team postponed the vote twice due to high workloads and because the teaching faculty asked for further information about the innovation. At T3, the principal, leadership team, and teachers reported their doubts around obtaining a positive vote, as they still felt that there was some uncertainty among the teaching faculty (teachers' perceptions-perceived benefits-and-costs ratio). The vote finally took place shortly after T3. The majority of teachers voted against the transformation into an all-day school.

\begin{abstract}
"Well, I think that we have done everything that we could do in terms of communication and transparency. We were truly honest and transparent and have emphasized regularly: 'This is our goal; this is what we want to achieve.'Surprisingly, there was suddenly very strong resistance [...]." (member of the leadership team, Tokyo, T3).
\end{abstract}

With regard to teacher collaboration, we found evidence of both low-cost (teacher collaboration - exchanging information) and high-cost forms of collaboration (teacher collaboration-shared workload, joint work). On the one hand, several interviewees reported some group discussions over the course of our study (e.g., the leadership team presenting and discussing ideas with teachers in a staff conference; staff council

\footnotetext{
${ }^{3}$ The staff council is a group of teachers elected from the teaching faculty for a limited amount of time. They represent the teaching faculty's interests and regularly organize staff meetings to discuss teachers' concerns.
} 
discussing concerns with teachers; teacher, T1; staff council, T2). On the other hand, interviewees reported that at least one project-specific group was actively working on the innovation project (principal, T3; member of the leadership team, T3). However, despite the leadership team's efforts to support teachers' commitment and participation in decision-making processes and respond to their concerns and uncertainties, the innovation failed due to a negative vote by the teaching faculty.

The school Cape Town: The innovation initially planned for the school Cape Town focused on revising the school's concept for students' self-organized learning (leadership - setting goals and developing strategies). This idea was proposed by the principal and vice principal, who recognized that teachers and students were not satisfied with how students had recently been working in phases of self-organized learning. However, neither teachers nor the steering group ${ }^{4}$ were able to report on the desired innovation at T1, as they had not yet been informed by the principal or vice principal. Instead, several interviewees reported teachers perceiving a lack of communication from the leadership team and steering group (leadership —strategic communication).

"We on the staff council have told the principal that we would like a list of things that the steering group and also the other working groups at the school are actually doing. That way, we teachers know who is assigned what role and what task, and we can contact these people. [...] At the moment, nobody really knows who is doing what and who is responsible for what." (teacher, member of the staff council, Cape Town, T1).

From T2 on, Cape Town received support from an external consultant who was sent by the Ministry of Education, as the teaching faculty had previously filed a complaint due to high workloads and little time for organizational change. This external consultant, who was formerly a principal of a school that was awarded the German school award, contributed to the change process in three ways. First, she chaired meetings of the leadership team and teaching faculty that were aimed at pinpointing school goals and strategies for organizational change. As a result, the school Cape Town changed its innovation project and began focusing on revising the teaching schedule with the aim of developing a new concept for students' self-organized learning (leadership setting goals and developing strategies). Second, the external consultant initiated project-specific groups consisting of teachers who volunteered to take part by working collaboratively on tasks related to the innovation (teacher collaboration-shared workload, joint work). Third, she enhanced the steering group's involvement in the change process, as each member of the steering group was supposed to participate in one of the project-specific groups (leadership -involving teachers in decision making, teacher collaboration-interdependence). Finally, the leadership team-supported by the external consultant- took a vote on the innovation, which resulted in the majority of teachers voting in favor of the innovation.

\footnotetext{
${ }^{4}$ The steering group at the school Cape Town had been in place for several years and consisted of the principal, several teachers, the school's social worker, parents, and an external consultant sent by the Ministry of Education in order to obtain a quality certificate.
} 
"We received support from an external consultant, who came here for a staff conference and helped us in pinpointing core themes. It took place on a day when all of the teachers were present. They thought about what they wanted to change and what was stressing them-about what they needed and what they wanted to keep. The teaching schedule was a big issue: 'What does the schedule look like? Is it necessary that classes take place so late in the afternoon?' [...] And then she came here again after the summer break when we tried to make the whole idea more specific." (principal, Cape Town, T2).

As reported from different perspectives at T3, the external consultant helped to increase the motivation of teachers to participate in the change process (member of the leadership team 1, T2). Teachers continued to meet in staff conferences and project-specific groups to prepare for the implementation of the innovation. Interviewees felt, however, that the principal contributed relatively little to this positive shift, as he was lacking a vision for the school (teacher, member of the steering group 1, T3). Additionally, interviewees reported on teachers' uncertainty around the school's future, as there were rumors that Cape Town was supposed to be merged with a neighboring school (teachers' perceptions-knowledge related to the innovation). This made teachers hesitant to take on additional work to achieve the organizational change (teachers' perceptions - resistance to the innovation).

\begin{abstract}
"Some time ago they said: 'This is the only chance to have a unique feature as an all-day school.' Otherwise we wouldn't have done this back then. [...] And then there was the merger [with the other school], which gets in the way of many things. I notice it myself. Of course, I do my job, because I'm doing it for the school. It's my school, but it's incredibly hard when you think, 'What am I doing this for if it's worth nothing in the end? '" (teacher, member of the steering group 1, Cape Town, T3).
\end{abstract}

With regard to teacher collaboration, we find evidence that is in part contradictory, yet points in a positive direction for the school Cape Town. In terms of low-cost collaboration (teacher collaboration-exchange of information), interviewees reported regularly scheduled meetings of the leadership team (i.e., weekly), the steering group (i.e., monthly), and the teaching faculty (i.e., monthly), in which team members discussed recent news and concerns. However, we found opposing evidence for the exchange of information between different groups. For instance, while the leadership team and the steering group reported that they had provided teachers with information about the change process (i.e., sending out protocols with meeting results), teachers reported a lack of information and a desire for more transparency. In turn, members of the steering group reported a lack of participation and commitment to the organizational change from the teachers (teacher, member of the steering group 2, T1). In terms of high-cost forms of collaboration, interviewees reported an increase in sharing workloads and joint work in project-specific groups from T2 onward. These forms of collaboration mainly took place in a series of meetings that were initiated by the external consultant and provided the whole school staff with fixed time periods to collaboratively work on the implementation of the innovation. 
"She is coordinating the whole process. The teachers say 'We want to hold a staff conference' and she talks to the leadership team about how to plan it. She tries to find out what the needs are [...] and then she works with the teachers to develop a vision. [...] We have planned to have several afternoons during the year where we have time to get together and work collaboratively on different aspects of school improvement. Then the proposals are voted on at the conferences. She is monitoring and leading the whole process, yes." (member of the leadership team, Cape Town, T3).

In sum, we found evidence of a turnaround in Cape Town's change process around T2. At T1, interviewees reported unclear goal setting, a lack of communication, and little motivation of teachers to participate in the change process. Overall, the principal was hardly mentioned with regard to organizational change in either of the interviews at $\mathrm{T} 1$. However, from $\mathrm{T} 2$ on, interviewees reported perceiving an improved vision for the school's innovation and an increase of collaboration in project-specific groups. While they also perceived an increase in teachers' motivation to participate in the change process, some of the teaching staff were still undecided about participating in the change process due to their previous experiences with failed innovations and uncertainties about the school's future (teachers'perceptions-innovativeness, collective efficacy, perceived benefits-and-costs ratio).

The school Oslo: The principal of the school Oslo implemented two substantial innovations to the school's organization after starting in his position in 2016 (before the beginning of our study). First, the principal introduced a new strategic approach to organizational change that would structure innovation processes in two-year cycles (leadership -setting goals and developing strategies). In preparation for each cycle, the leadership team organized a staff conference ${ }^{5}$ in which they collected suggestions from teachers for future innovations. The staff then voted on the suggestions they found most relevant at the staff conference and volunteered to work in projectspecific groups to implement the approved innovations (teachers 'perceptions-perceived benefits-and-costs ratio, leadership -involving teachers in decision making). For this reason, the school Oslo-unlike the schools Tokyo and Cape Town-implemented more than one innovation during our study (see Table 2).

The principal of the school Oslo introduced collaborative networks of teachers on different levels of the school organization. First, he created an extended leadership team with the aim of sharing administrational responsibilities and workload (school structure). The extended leadership team consisted of nine teachers with different functions (e.g., year-level managers). ${ }^{6}$ Second, because teachers had reported a perceived lack of transparency in a formal evaluation conducted by the extended leadership team, the principal created groups of teachers to support communication within the school and involve teachers in decision-making processes (leadership-strategic communication, involving teachers in decision making). For instance, he initiated

\footnotetext{
5 The staff conference at the school Oslo consists of the entire teaching staff and the leadership team.

${ }^{6}$ The staff at school Oslo is structured differently due to its high number of teachers (see Table 2). For this reason, there are more and different types of middle managers (e.g., year-level managers) compared to schools Tokyo and Cape Town.
} 
what was called an instructional committee, which consisted of the department heads of each subject (e.g., STEM, arts, and languages). The instructional committee was supposed to support collaboration between subject departments, as well as between the leadership team and subject departments, as it regularly organized meetings to discuss news and concerns (teacher collaboration - norms and standards for teacher collaboration, interdependence).

"Well, basically I want to see all aspects of school improvement being implemented somewhere in the school, that is, organizational change, staff development, and instructional improvement-and a specific committee for every aspect." (principal, Oslo, T1).

Moreover, the principal initiated a steering group to coordinate the work of projectspecific groups that were initiated as part of the innovation cycle. The steering group consisted of the principal, another member of the leadership team, and teachers who were elected by the teaching faculty for the duration of each innovation cycle (leadership - involving teachers in decision making). Every teacher in the steering group also served as a spokesperson for a project-specific group in order to facilitate the exchange of information about work-related updates and questions between both groups (teacher collaboration-interdependence). As reported by several interviewees at T3, seven project-specific groups had been implemented throughout our study to work on different sub-projects related to organizational change (e.g., creating a concept for PD, reconstruction of the staff room). Almost half of the teaching faculty were involved in one of the project-specific groups (leadership - involving teachers in decision making; member of the leadership team, T2). At T3, several interviewees reported feeling that teachers welcomed the new collaborative approach because they were able to participate in decision-making processes and, thus, felt efficacious. Also, interviewees reported that six out of seven project-specific groups had implemented their innovations successfully.

"[...] This keeps teachers from feeling that things are organized from the top down. Especially in the case of the group on professional development, the initiative came from the teachers. It was young teachers who worked on the topic. It's not like the principal was saying: 'We have to implement this in our school.' It was in the teachers' interest. I think this is hugely beneficial for every subject [...]." (teacher, member of the instructional committee, Oslo, T3).

Similar to the school Tokyo, at Oslo, we found evidence of both low-cost and highcost forms of collaboration. With regard to low-cost forms of collaboration, interviewees reported numerous situations in which teachers exchanged knowledge and experience and discussed questions and concerns (i.e., in staff conferences or groupspecific meetings). For instance, the extended leadership team, the instructional committee, and the steering group each reported on regular meetings to discuss news and updates. At the start of each meeting of the steering group, project-specific groups were supposed to report updates on their progress (teacher collaboration-norms and standards for teacher collaboration). Moreover, the project-specific groups were 
supposed to post all work-related updates on a message board in the school building to keep the teaching faculty informed about recent developments (teacher collaboration-norms and standards for teacher collaboration). With regard to high-cost forms of collaboration, interviewees reported on joint work by teachers in projectspecific groups. In these groups, teachers developed ideas and strategies for the change process, and implemented and evaluated their innovations collaboratively.

"I really think that the idea of having project-specific groups is very positive, because there are a lot of things where people said, 'This is something we need and this is something we should do, 'but no one ever felt responsible. [...] And now, there is a group that is in charge of that. This is, I guess, more effective than when people just talk about changing something and make plans, but in the end nobody feels responsible." (teacher, member of the instructional committee, Oslo, T3).

\section{Cross-case analyses}

We used cross-case analyses to compare longitudinal changes in all three schools. This allowed us to identify four themes of leadership practices that might have supported teacher collaboration and, hence, contributed to the organizational change in the schools:

(1) setting goals and developing strategies for implementing innovations,

(2) involving teachers in decision making,

(3) supporting teacher teams on the process level,

(4) supporting teacher teams on the motivational level.

(1) First of all, principals need to set a clear vision for their school and develop a strategy for how to implement innovations (e.g., who to involve in the implementation process, what to communicate to the school community). We found that the principal of the school Oslo had a clear idea of the school's long-term goal, as he strove to improve the overall instructional quality by improving teachers' participation in decision making and their perceived efficacy. In order to reach this goal, the school Oslo structured the change process in two-year long cycles in which teacher teams could bring up ideas for innovations, obtain feedback from the teaching faculty, and collaboratively work on implementing innovations. The principal intentionally limited each cycle as he intended to involve as many teachers as possible in the change processes and decrease additional workload on teachers. Moreover, he wanted to carry out innovations properly in order to collectively reflect on and evaluate outcomes, and use these insights for future innovations.

"We would like to keep the cyclical structure. First of all, because this allows us to work on several projects simultaneously, to really conduct the plan-docheck-act cycle and not lose too much time. But also, to reduce teachers'stress 
when we say 'You have two years for that.' If I'm faster, it's fine; if not, I'm not too slow." (principal, Oslo, T2).

The principal of school Cape Town, on the other hand, appeared to lack a clear vision for the school. As different interviewees reported throughout our study, the principal was reluctant to make decisions and, hence, failed to create a clear strategy for implementing the innovation (member of the leadership team, Cape Town, T3). This was confirmed by the principal himself as he reflected on his pedagogical beliefs and questioned his qualification as a principal at T3. However, as the school Cape Town received support from an external consultant, interviewees reported a turnaround at T2 (member of the leadership team, Cape Town, T2). This external consultant seemed to compensate for the perceived lack of leadership as she set clear goals for the change process, created teacher teams, and, hence, promoted the change process at school Cape Town. At T3, several interviewees reported feeling that the external advisor was the main factor contributing to a positive trend in the school's change process (member of the staff council, Cape Town, T3).

"[...] I have some ideas about what principals are supposed to do, but I'm not sure if I want to do things that way: [...] 'This is my idea and this is how it's supposed to improve things.' I have no idea if I'm going to improve things. I also have no idea if I'm going to make things worse. I'm unsure about the outcome. And I kind offeel that as a confident principal, I ought to be confident and say: 'We're going to do this in a different way'. [...] And I have realized that's not how I am. I need to find my own approach.” (principal, Cape Town, T3).

"Without [name of the external consultant], we wouldn't have achieved what we did. We definitely wouldn't have managed on our own" (teacher, member of the steering group, Cape Town, T3).

Similar to the principal at the school Oslo, the principal at the school Tokyo also reported a clear vision for the school and strategies for its implementation. However, she failed to convince teachers of the innovation's relevance, which led to the majority of teachers voting against it. This suggests that there are further factors that can support organizational change that go beyond strategies for setting and developing goals, as we will discuss in the following sections.

(2) Principals can involve teachers in decision making with regard to planning and implementing innovations. This promotes teachers' sensemaking of innovations. We assume that when teachers perceive innovations as plausible and relevant, they are more motivated to participate. As interviewees from the school Oslo reported, almost half of the teaching faculty contributed to one of the many project-specific groups (member of the leadership team, school Oslo, T2). It is plausible that this motivation derived from teachers being involved in narrowing down ideas for innovations in the first place. As different interviewees reported at T3, this motivated teachers to participate because they expected success and felt efficacious.

"You see, there were a lot of people who contributed to these project-specific groups. And they were doing it on top of their own classes and on top of every- 
thing else they have to do. I think that shows a lot of motivation. When people recognize that they can really change something, when there is something that is relevant, they are willing to contribute. I think that is impressive." (teacher, member of the steering group, Oslo, T3).

Our results also indicate that when teachers perceive an overall adverse ratio between an innovation's relevance and its costs, teachers will reject the organizational change and prefer to stick to existing practices. While we found evidence of teachers' concerns over increased workloads related to the innovation for all of the schools in the present study, teachers from the school Tokyo appeared to be particularly reluctant. We assume that they did not perceive the anticipated innovation to be relevant, as they had rejected the innovation once before our study and voted against the innovation after T3. Although several interviewees reported that teachers were usually provided the opportunity to contribute to planning ideas, they were not involved in developing the present idea. Instead, the current innovation was initiated by the principal and the leadership team at the school Tokyo (member of the leadership team, Tokyo, T1). Moreover, interviewees reported teachers' concerns over a lack of support from the district administration with regard to sufficient school staff and spaces in the school building for the innovation.

"As I said, they are mainly worried about the time they spend in school. This is a real problem. I do recognize this, because-and this is where things have come full circle-we have to build an addition to the school building because we don't have enough space for teachers to work properly." (member of the leadership team, Tokyo, T3).

"[...] because we don't trust the district administration with regard to financial issues and the new building we are supposed to get. So, it's actually not related to the principal, but to the overall context. This makes it difficult for us to really trust the project and say, 'This will turn out fine and everything will be done quickly'." (teacher, member of the steering group, Tokyo, T3).

(3) Our study suggests that principals can support teacher teams on the process level in two ways. First, they can help teachers to initiate teams and provide these teams with consistent time slots to meet, discuss, and work collaboratively on innovations. These teams ideally consist of teachers who volunteer to participate and share ideas and workloads, and work together on the innovation. For all of the schools in the present study, we found that teams of teachers were created to promote organizational change in some way. We found evidence of a steering group and project-specific groups initiated by the principal and external consultant at the Tokyo and Cape Town schools, respectively. With regard to the school Oslo, however, we found a wellestablished culture of collaboration that set clear standards for processes of joint work among teachers. In particular, the principal of the school Oslo created teams at different hierarchical levels (e.g., extended leadership team, instructional committee, steering group, project-specific groups). 


\begin{abstract}
"The instructional committee is responsible for instructional improvement. This is a new team that we created. And honestly, this is something we didn't discuss much. But I suggested this structure. [...] It is a group consisting of the heads of the subject departments. [...] The steering group coordinates school improvement, which means that they are not working on implementing initiatives, but that they support the individual project-specific groups. So, they are taking care of connecting the project-specific groups with the leadership team and other people that might be important, like the ministry or the district administration. And they also take care of the communication between the project-specific groups and the teaching faculty, so there is a constant exchange of information and high accountability [...]." (principal, Oslo, T1).
\end{abstract}

Second, principals can guide teacher teams and help them to set internal goals, create within-group accountability, monitor progress, and exchange information on work-related news with colleagues outside the group. This is important, as teachers are usually not trained to manage organizational change and, therefore, might lack knowledge and skills related to project management. At the school Oslo, the principal established a clear distribution of tasks, which helped to create responsibility within the group and transparency toward the teaching faculty (i.e., extended leadership team; principal, Oslo, T3). Moreover, the principal supported project-specific groups by providing tools for project management (e.g., setting deadlines, supporting clear communication, tracking progress on publicly accessible message boards) and creating a culture of transparent information sharing.
"And the groups that have used this, for example, the professional development concept group [...] have used the charts and have achieved great results; they have developed internal goals and so on. Then there are others that haven't used it and were still successful [...]. But every group has its message board here, so at least they have a starting point. They have reflected on this fully at least once. And we hope that this turns into something sustainable. We were able to give them feedback that the groups that have worked well were the ones that have used these professional tools in some way." (principal, Oslo, T3).

Interviewees also reported high levels of interdependence between the steering group and project-specific groups, as each of them had a spokesperson who was also a member of the steering group and shared information in internal meetings (similar structures were reported for the instructional committee and subject departments; teacher, member of the steering group, Oslo, T3).

"We organized it in such a way that one member of the steering group was the contact for a project-specific group, sometimes participated in their meetings, and always organized things: 'When are you going to present something to the teaching faculty? Do you need a contact? Shall I contact someone outside the school, the principal, etcetera?' They have been a kind of a connecting link." (principal, Oslo, T2). 
Interviewees at the schools Tokyo and Cape Town also reported collaborative structures. However, these forms of collaboration did not seem to follow specific standards and procedures. For instance, although the school Tokyo created a steering group for the purpose of implementing the innovation, this group of school staff contributed little to the change process as they met very infrequently (teacher, member of the steering group, Tokyo, T3). The steering group at the school Cape Town was reported by the teaching faculty at T1 to work mainly in isolation (teacher, member of the staff council, Cape Town, T1). For this reason, teachers knew very little about their work. However, this changed when the external consultant initiated project-specific groups and promoted the steering group's participation from T2 on.

"This was done by [name of the external consultant] at our first big meeting. We created teams of interested teachers [...] and they thought about what they would change. [...] Then we summarized all the aspects and evaluated them. That was what [name of the external consultant] did." (principal, Cape Town, T2).

(4) Principals can support teacher teams on the motivational level by providing teachers with autonomy, creating positive error management, and responding to teachers' concerns. We found for the school Oslo-but not for the schools Tokyo or Cape Town - that principals were able to promote teachers' sense of autonomy by delegating individual decision making to teacher teams and only providing support where it was needed. As the principal of the school Oslo emphasized, he intended to create organizational change on the basis of the school staff's consensus. Teachers were not forced to participate, but were asked to contribute voluntarily.

"I don't lead by saying, 'This is how we do things,' but by providing the working conditions for teachers to work in a good way and achieve results, by not demotivating them, and by guaranteeing efficiency. This is what the collaborative structures were intended to achieve: to make teachers feel empowered and capable of contributing to the school. And to make them feel that the school is based on shared norms and visions. [...] But no one is obliged to do more than their required teaching." (principal, Oslo, T1).

Moreover, the principal reported his intention to create a positive error management culture in order to retain high levels of teacher motivation. Several interviewees reported their observation at T3 that the principal of Oslo accepted the fact that one project-specific group did not implement its innovation successfully. Instead, the principal considered this an opportunity to reflect on future changes in practices of organizational change.

"[...] I need to accept that, for example, one group might work in a different way than I would. Or that they work at a slower pace or achieve different results. Or that the results match my expectations by only $70 \%$ with regard to quality or quantity. But I am convinced that it's always better if a school works 
together to achieve 70\% than if I try to achieve 100\% on my own." (principal, Oslo, T3).

"Well, we have seen that there might be projects [...] that haven't reached their goals. But this is something that was emphasized from the beginning, that failing might be an option." (teacher, member of the steering group, Oslo, T3).

As organizational change produces discontinuity in established practices, it enhances teachers' perceptions of uncertainty and stress. Our results suggest that support from the principal (or someone else who is responsible for leading change) might reduce this stress, as principals can emphasize an innovation's relevance and usefulness. For instance, we found evidence of a positive turnaround in teachers' attitudes toward change at the school Cape Town around T2. As reported, this turnaround was mainly initiated by the external consultant, who supported the change process and promoted teachers' motivation. However, we found a negative turnaround of teachers' attitudes toward change at the school Tokyo at T2. While the principal and the leadership team reported making different attempts to address teachers' concerns, they were not able to change the concerns (principal, Tokyo, T3).

"It is a huge problem that our teachers see that they have to spend more than two afternoons here. We also have conferences every Friday, and then they have to stay longer three or four times a week. This is what they are afraid of, and they told the principal that [...]. " (teacher, member of the steering group, Tokyo, T2).

\section{Discussion}

In the present study, we assumed principal leadership to be a facilitator of teacher collaboration for organizational change. We investigated the research question, drawing on longitudinal qualitative data from three schools in Germany. We presented findings on a school that failed to implement its innovation (Tokyo), a school that successfully implemented several innovations (Oslo), and a school with pending outcomes of the change process (Cape Town). Based on our results, we developed four specific assumptions on how principals' leadership practices can facilitate and support teacher collaboration and, hence, contribute to organizational change. In the following, we will discuss the assumptions in light of the current body of research and their practical implications.

(1) Principals need to set a clear vision for their school and develop a strategy for how to implement innovations This finding coincides with other evidence demonstrating that processes of organizational change need to be goal-oriented and clearly structured in order to be implemented effectively (Day et al., 2016; Rikkerink et al., 2015; Sun \& Leithwood, 2015). Anticipated innovations to organizational practices need to be specific and consistent with one another (Desimone, 2002). If innovations 
are contradictory or imprecise, teachers are less likely to support their implementation (Cheng \& Walker, 2008).

(2) Principals can involve teachers in decision making with regard to planning and implementing innovations in order to increase their motivation to participate As previous research has shown, organizational innovations need to be perceived as plausible and relevant in order to be implemented successfully (Ala-Laurinaho et al., 2017; Bartunek et al., 2006). Being involved in decision making helps teachers make sense of planned innovations and increases their motivation to adapt professional practices (Thurlow \& Mills, 2014). In light of the findings of Lee et al. (2021), who reported poor correspondence between principals' and teachers' perceptions of aspects of school improvement (e.g., innovativeness of teachers, teacher participation), active involvement of teachers in school improvement might help to reduce disagreements. Drawing on expectancy-value theory (Wigfield \& Cambria, 2010; Wigfield \& Eccles, 2000), we assume that teachers will be motivated to participate in innovations when they value their importance, expect themselves to be successful, and perceive low costs related to the innovation (Bandura, 1993). Our results suggest that the more teachers are involved in decision making, the likelier it is that they will perceive innovations as useful and, in turn, collaboratively implement these innovations. This corresponds with evidence from Honingh and Hooge (2014), who found a relationship between participation in decision making and teacher collaboration for a sample of Dutch teachers.

(3) Principals can support teacher teams on the process level of organizational change First of all, principals can provide teachers with structural prerequisites for collaboration (e.g., consistent meeting times; Gray et al., 2016; Vangrieken et al., 2015). As observed at the school Oslo, they can help teachers to initiate teams by jointly pinpointing ideas for potential innovations. Based on their interests, teachers can then join groups so that they can have shared goals for their joint work. This finding is in line with results from Szczesiul and Huizenga (2014), who also found that clear goal setting and shared norms help teacher teams perform well. Without a common vision, teacher teams may lack orientation for their collaborative work (Truijen et al., 2013).

(4) Principals can support teacher teams on the motivational level of organizational change Drawing on self-determination theory (Deci \& Ryan, 2000), we assume that teachers will be more motivated to contribute to implementing innovations when they perceive themselves as acting autonomously in their collaborative work (Fix et al., 2020; Gagné et al., 2000; Hornung \& Rousseau, 2007). This corresponds with findings from Truijen et al. (2013). Moreover, principals can promote a climate of trust in their school, especially with regard to positive error management (Dyck et al., 2005). This allows teachers to make mistakes and, hence, encourages teachers to try to contribute to organizational change in the first place. At the same time, principals need to accept that results will not always correspond with their expectations, which is in line with results from Palumbo and Manna (2019). 


\section{Conclusion}

Based on both within-case and cross-case analyses of three school improvement initiatives, we developed four assumptions on how principals can support teacher collaboration and, hence, processes of organizational change. These assumptions provide practical implications for principals as examples of effective practices for school improvement. Principals can create a long-term vision for the school and set short-term goals that are in line with this vision. Principals can involve other school staff, such as further members of the leadership team and teachers, in this process to foster collective sensemaking of innovations and foster the overall motivation of school staff to participate in implementing these innovations. In this regard, principals can also help school staff to initiate teams, guide them on the process level, and provide them with autonomy to collectively plan and implement innovations. If principals lack the skills to initiate and monitor processes of organizational change, they can seek support from external consultants or coaches.

Our findings also have implications for school administration. As our results suggest, professional practices related to implementing innovations (e.g., project management skills) are important for both principals and teachers. Principal preparation and PD programs can consider this in two ways. First, they should train principals in initiating, monitoring, and evaluating innovations in their schools (Andreoli et al., 2019). In particular, our results highlight the important role of individual coaching by external consultants (e.g., administrational support by supervisors; Cape Town). Individual coaching of principals who struggle with leading changes might be an effective way to sustainably improve a school's capacity to change. Coaching allows principals to learn from experienced colleagues and see what works best in school improvement (Tahir et al., 2021). Second, preparation and PD programs should support principals in providing teachers with the knowledge and skills required for organizational change. Principals need to know how they can distribute tasks to teacher teams and equip them with the right tools to fulfill these tasks.

However, our findings should be interpreted keeping some methodological limitations in mind. First, we investigated a sample of only three schools. Although each case consists of multiple perspectives, transferability of our results to other contexts is limited. Second, we did not measure objective outcome variables (e.g., student achievement, teacher job satisfaction). Therefore, our interpretation of a school's success in implementing an innovation is solely based on the interviewees' subjective perceptions. Future studies should consider using mixed-method approaches in order to gain ample evidence. Third, the schools in the present study differ from each other with regard to student composition. As previous research has suggested, teachers at schools that serve disadvantaged communities (i.e., high proportion of low-SES students) often have low expectations of students, show dysfunctional relationships between staff members, and lack responsibility for students (Klein et al., 2021). This might contribute to a low motivation on the part of teachers to participate in activities that are additional to their teaching workload. In particular, quantitative studies should investigate the influence of school-level characteristics on organizational change. 
In sum, our study contributes to the current body of research in several ways. First, it provides in-depth insights into the relationship between principal leadership, teacher collaboration, and organizational change that to go beyond the simple description of structures and processes. In particular, our study provides evidence on how principals can support the motivation of school staff to participate in change processes. Second, only a few studies have investigated longitudinal interview data using within-case and cross-case analyses to generate insights into mechanisms of implementing innovations in schools. Our study provides comprehensive evidence with regard to the process of planning and implementing innovations in schools. On the basis of our results, we developed four specific assumptions on potential causal relationships between principal leadership, teacher collaboration, and organizational change in schools. These relationships should be investigated in future research. Moreover, we highlighted the relevance of distributed leadership practices and the role of members of the leadership team, middle managers, teacher leaders, and external consultants as change agents for the implementation of innovations in schools.

\section{Appendix}

Table 4 Coding scheme

\begin{tabular}{|c|c|c|}
\hline Code name & Source & Definition \\
\hline School structure & $\begin{array}{l}\text { Marks \& Seashore } \\
\text { Louis, } 1999\end{array}$ & \\
\hline $\begin{array}{l}\text { Obligatory formal } \\
\text { structures }\end{array}$ & $*$ & $\begin{array}{l}\text { Formal collaborative activities obligatory for school staff, } \\
\text { e.g., staff conferences }\end{array}$ \\
\hline $\begin{array}{l}\text { Non-obligatory } \\
\text { formal structures }\end{array}$ & $*$ & $\begin{array}{l}\text { Formal collaborative activities not obligatory for school } \\
\text { staff, but implemented voluntarily, e.g., steering groups, } \\
\text { project-specific groups }\end{array}$ \\
\hline $\begin{array}{l}\text { Informal } \\
\text { structures }\end{array}$ & $*$ & $\begin{array}{l}\text { Informal collaborative activities of school staff, e.g., loose } \\
\text { networks of teachers }\end{array}$ \\
\hline Leadership & $\begin{array}{l}\text { Marks \& Seashore } \\
\text { Louis, } 1999\end{array}$ & \\
\hline $\begin{array}{l}\text { Providing teachers } \\
\text { with autonomy }\end{array}$ & Fix et al., 2020 & $\begin{array}{l}\text { Leadership practices that promote teachers' autonomy with } \\
\text { regard to participating in change processes }\end{array}$ \\
\hline $\begin{array}{l}\text { Involving teach- } \\
\text { ers in decision } \\
\text { making }\end{array}$ & $\begin{array}{l}\text { Rikkerink et al., } \\
2015\end{array}$ & $\begin{array}{l}\text { Leadership practices that involve teachers in decision } \\
\text { making with regard to organizational change, e.g., finding } \\
\text { innovations, developing strategies, implementing change }\end{array}$ \\
\hline $\begin{array}{l}\text { Setting goals } \\
\text { and developing } \\
\text { strategies }\end{array}$ & $\begin{array}{l}\text { Leithwood \& } \\
\text { Jantzi, } 2005 \\
\text { Schechter, } 2008\end{array}$ & $\begin{array}{l}\text { Leadership practices that aim at setting short-term and } \\
\text { long-term goals for organizational change, as well as } \\
\text { leadership practices with regard to developing strategies } \\
\text { for implementing innovations }\end{array}$ \\
\hline $\begin{array}{l}\text { Strategic } \\
\text { communication }\end{array}$ & Feldhoff, 2011 & $\begin{array}{l}\text { Leadership practices that aim at deliberately communicat- } \\
\text { ing information related to the innovation, e.g., forwarding } \\
\text { specific information to specific people at a specific time } \\
\text { point }\end{array}$ \\
\hline $\begin{array}{l}\text { Dealing with } \\
\text { conflicts and } \\
\text { resistance }\end{array}$ & $*$ & $\begin{array}{l}\text { Leadership practices that aim at dealing with concerns and } \\
\text { resistance from teachers with regard to the innovation }\end{array}$ \\
\hline
\end{tabular}


Table 4 Coding scheme

\begin{tabular}{|c|c|c|}
\hline Code name & Source & Definition \\
\hline $\begin{array}{l}\text { Representing in- } \\
\text { terests of teachers }\end{array}$ & $*$ & $\begin{array}{l}\text { Principals supporting interests of teachers when designing } \\
\text { and implementing innovations; principals advocating for } \\
\text { the interests of teachers }\end{array}$ \\
\hline Teachers' perceptions & $\begin{array}{l}\text { Marks \& Seashore } \\
\text { Louis, } 1999\end{array}$ & \\
\hline Shared goals & $\begin{array}{l}\text { Marks \& Seashore } \\
\text { Louis, 1999; } \\
\text { Voelkel \& Chrisp- } \\
\text { eels, } 2017\end{array}$ & $\begin{array}{l}\text { Teachers sharing the same vision and goals for organiza- } \\
\text { tional change }\end{array}$ \\
\hline Teachers' perceptions & $\begin{array}{l}\text { Marks \& Seashore } \\
\text { Louis, } 1999\end{array}$ & \\
\hline $\begin{array}{l}\text { Knowledge related } \\
\text { to the innovation }\end{array}$ & $\begin{array}{l}\text { Feldhoff, } 2011 \\
\text { Marks \& Seashore } \\
\text { Louis, } 1999\end{array}$ & $\begin{array}{l}\text { Teachers reporting details related to the change process } \\
\text { with regard to planning and implementing innovations }\end{array}$ \\
\hline $\begin{array}{l}\text { Collective teacher } \\
\text { efficacy }\end{array}$ & $\begin{array}{l}\text { Gray \& Summers, } \\
2015\end{array}$ & $\begin{array}{l}\text { Teachers sharing the belief that innovations can imple- } \\
\text { mented successfully by the teaching staff }\end{array}$ \\
\hline $\begin{array}{l}\text { Perceived } \\
\text { benefits-and-costs } \\
\text { ratio }\end{array}$ & $\begin{array}{l}\text { Wigfield \& } \\
\text { Eccles, } 2000\end{array}$ & $\begin{array}{l}\text { Teachers gauging the personal/professional benefits and } \\
\text { costs related to the implementation of an innovation }\end{array}$ \\
\hline Innovativeness & $\begin{array}{l}\text { Gray \& Summers, } \\
2015\end{array}$ & $\begin{array}{l}\text { Teachers' motivation to change established professional } \\
\text { and organizational practices }\end{array}$ \\
\hline $\begin{array}{l}\text { Discontent with } \\
\text { prior/current } \\
\text { situation }\end{array}$ & $*$ & $\begin{array}{l}\text { Teachers being unhappy with organizational practices that } \\
\text { they might want to change }\end{array}$ \\
\hline $\begin{array}{l}\text { Resistance toward } \\
\text { the innovation }\end{array}$ & $*$ & $\begin{array}{l}\text { Teachers showing active and passive resistance towards } \\
\text { the innovation of specific professional/organizational } \\
\text { practices }\end{array}$ \\
\hline Teacher collaboration & $\begin{array}{l}\text { Marks \& Seashore } \\
\text { Louis, } 1999\end{array}$ & \\
\hline $\begin{array}{l}\text { Exchange of } \\
\text { information }\end{array}$ & Gräsel et al., 2006 & $\begin{array}{l}\text { School staff sharing ideas, experience, concerns, and ques- } \\
\text { tions with regard to the innovation }\end{array}$ \\
\hline Shared workload & Gräsel et al., 2006 & $\begin{array}{l}\text { School staff sharing tasks and responsibilities related to the } \\
\text { innovation }\end{array}$ \\
\hline Joint work & Gräsel et al., 2006 & $\begin{array}{l}\text { School staff establishing teams for working jointly on tasks } \\
\text { related to the innovation }\end{array}$ \\
\hline $\begin{array}{l}\text { Norms and stan- } \\
\text { dards for teacher } \\
\text { collaboration }\end{array}$ & $\begin{array}{l}\text { Hoy \& Sweetland, } \\
2001\end{array}$ & $\begin{array}{l}\text { Teacher teams having established norms for working to- } \\
\text { gether, e.g., assigning roles and responsibilities within the } \\
\text { team, implementing procedures for meetings }\end{array}$ \\
\hline Interdependence & $\begin{array}{l}\text { Johnson \& John- } \\
\text { son, } 2009\end{array}$ & $\begin{array}{l}\text { Teacher teams having assigned responsibilities within the } \\
\text { group and, hence, creating a relationship between an indi- } \\
\text { vidual's contribution and the whole group's achievement; } \\
\text { also having assigned responsibilities within the whole } \\
\text { school to different teacher teams and, hence, creating a } \\
\text { relationship between an individual group's contribution } \\
\text { and the overall innovation }\end{array}$ \\
\hline Quantity & $*$ & $\begin{array}{l}\text { Number of occasions for teachers to work together, i.e., } \\
\text { exchanging information, sharing workload, working jointly }\end{array}$ \\
\hline
\end{tabular}

*Category was developed inductively from the material

Funding Open Access funding enabled and organized by Projekt DEAL. 
Declaration of conflicting interests The author(s) declared no potential conflicts of interest with respect to the research, authorship, and/or publication of this article. The data were collected as part of the evaluation of the professional development program Werkstatt Schule leiten, which was funded by Die Deutsche Schulakademie.

Open Access This article is licensed under a Creative Commons Attribution 4.0 International License, which permits use, sharing, adaptation, distribution and reproduction in any medium or format, as long as you give appropriate credit to the original author(s) and the source, provide a link to the Creative Commons licence, and indicate if changes were made. The images or other third party material in this article are included in the article's Creative Commons licence, unless indicated otherwise in a credit line to the material. If material is not included in the article's Creative Commons licence and your intended use is not permitted by statutory regulation or exceeds the permitted use, you will need to obtain permission directly from the copyright holder. To view a copy of this licence, visit http:/creativecommons.org/ licenses/by/4.0/.

\section{References}

Adams, W. C. (2015). Conducting semi-structured interviews. In K. E. Newcomer, H. P. Hatry, \& J. S. Wholey (Eds.), Handbook of practical program evaluation (pp. 492-505). Hoboken: John Wiley \& Sons, Inc. https://doi.org/10.1002/9781119171386.ch19

Ala-Laurinaho, A., Kurki, A. L., \& Abildgaard, J. S. (2017). Supporting sensemaking to promote a systemic view of organizational change - Contributions from activity theory. Journal of Change Management, 17(4), 367-387. https://doi.org/10.1080/14697017.2017.1309566

Amels, J., Krüger, M. L., Suhre, C. J., \& van Veen, K. (2020). The relationship between primary school leaders' utilization of distributed leadership and teachers' capacity to change. Educational Management Administration \& Leadership. https://doi.org/10.1177/1741143220915921

Andreoli, P. M., Klar, H. W., Shawn Huggins, K., \& Buskey, F. C. (2019). Learning to lead school improvement: An analysis of rural school leadership development. Journal of Educational Change, 21, 517-542. https://doi.org/10.1007/s10833-019-09357-z

Askell-Williams, H., \& Koh, G. (2020). Enhancing the sustainability of school improvement initiatives. School Effectiveness and School Improvement, 31, 1-19. https://doi.org/10.1080/09243453.2020.17 67657

Austin, M. S., \& Harkins, D. A. (2008). Assessing change: Can organizational learning "work" for schools? The Learning Organization, 15(2), 105-125. https://doi.org/10.1108/09696470810852302

Bandura, A. (1993). Perceived self-efficacy in cognitive development and functioning. Educational Psychologist, 28(2), 117-148. https://doi.org/10.1207/s15326985ep2802_3

Bartunek, J. M., Rousseau, D. M., Rudolph, J. W., \& DePalma, J. A. (2006). On the receiving end. Sensemaking, emotion, and assessments of an organizational change initiated by others. The Journal of Applied Behavioral Science, 42(2), 182-206. https://doi.org/10.1177/0021886305285455

Berkemeyer, N., \& Holtappels, H. G. (2007). Arbeitsweise und Wirkungen schulischer Steuergruppen. Empirische Studie zur Steuerung der Schulentwicklungsarbeit im niedersächsischen Projekt „,Qualitätsentwicklung in Netzwerken“ [Working procedures and effects of steering groups. Empirical findings on school improvement initiatives in the project „Using networks for quality improvement” in Lower-Saxony]. In N. Berkemeyer, \& H. G. Holtappels (Eds.), Schulische Steuergruppen und Change Management [Steering groups and change management in schools] (pp. 99-138). Juventa

Cheng, Y. C., \& Walker, A. (2008). When reform hits reality: The bottleneck effect in Hong Kong primary schools. School Leadership and Management, 28(5), 505-521. https://doi. org/10.1080/13632430802499994

Day, C., Gu, Q., \& Sammons, P. (2016). The impact of leadership on student outcomes: How successful school leaders use transformational and instructional strategies to make a difference. Educational Administration Quarterly, 52(2), 221-258. https://doi.org/10.1177/0013161X15616863

Deci, E. L., \& Ryan, R. M. (2000). The "what" and "why" of goal pursuits: Human needs and the self-determination of behavior. Psychological Inquiry, 11(4), 227-268. https://doi.org/10.1207/ S15327965PLI1104 01

Desimone, L. (2002). How can comprehensive school reform models be successfully implemented? Review of Educational Research, 72(39), 433-479. https://doi.org/10.3102/00346543072003433 
Feldhoff, T. (2011). Schule organisieren. Der Beitrag von Steuergruppen und Organisationalem Lernen zur Schulentwicklung [Organizing schools. How steering groups and organizational learning contribute to school improvement]. VS Verlag

Feldhoff, T., Huber, S., \& Rolff, H. G. (2010). Steering groups as designers of school development processes. The Journal of Educational Research, 2, 98-124

Feldhoff, T., Kanders, M., \& Rolff, H. G. (2008). Schulleitung und innere Schulorganisation [Principals and school organization]. In H. G. Holtappels, K. Klemm, \& H. G. Rolff (Eds.), Schulentwicklung durch Gestaltungsautonomie: Ergebnisse der Begleitforschung zum Modellvorhaben "Selbstständige Schule” in Nordrhein-Westfalen [School autonomy and school improvement. Results from the evaluation of ,Autonomous schools “ in North Rhine-Westphalia] (pp. 146-173). Waxmann

Fix, G. M., Rikkerink, M., Ritzen, H. T. M., Pieter, J. M., \& Kuiper, W. A. J. M. (2020). Learning within sustainable educational innovation: An analysis of teachers' perceptions and leadership practice. Journal of Educational Change, 22, 1-15. https://doi.org/10.1007/s10833-020-09410-2

Gagné, M., Koestner, R., \& Zuckerman, M. (2000). Facilitating acceptance of organizational change: The importance of self-determination. Journal of Applied Social Psychology, 30(9), 1843-1852. https:// doi.org/10.1111/j.1559-1816.2000.tb02471.x

Gilley, A., Gilley, J., \& McMillan, H. (2009). Organizational change: Motivation, communication, and leadership effectiveness. Performance Improvement Quarterly, 21, 75-94. https://doi.org/10.1002/ piq. 20039

Gräsel, C., Fußangel, K., \& Pröbstel, C. (2006). Lehrkräfte zur Kooperation anregen - Eine Aufgabe für Sisyphos? [Fostering teacher collaboration-A Sisyphean task?]. Zeitschrift für Pädagogik, 52(2), 205-219

Gray, J., Kruse, S., \& Tarter, C. (2016). Enabling school structures, collegial trust and academic emphasis: Antecedents of professional learning communities. Educational Management Administration \& Leadership, 44(6), 875-891. https://doi.org/10.1177/1741143215574505

Gray, J. A., \& Summers, R. (2015). International professional learning communities: The role of enabling school structures, trust, and collective efficacy. International Education Journal: Comparative Perspectives, 14(3), 61-75

Honingh, M., \& Hooge, E. (2014). The effect of school-leader support and participation in decision making on teacher collaboration in Dutch primary and secondary schools. Educational Management Administration \& Leadership, 42, 75-98. https://doi.org/10.1177/1741143213499256

Hornung, S., \& Rousseau, D. (2007). Active on the Job-Proactive in Change. The Journal of Applied Behavioral Science, 43, 401-426. https://doi.org/10.1177/0021886307307555

Hoy, W., \& Sweetland, S. (2001). Designing better schools: The meaning and measure of enabling school structures. Educational Administration Quarterly, 37, 296-321. https://doi. org/10.1177/00131610121969334

Johnson, D. W., \& Johnson, R. T. (2009). An educational psychology success story: Social interdependence theory and cooperative learning. Educational Researcher, 38(5), 365-379. https://doi.org/10. 3102/0013189X09339057

Kelchtermans, G. (2006). Teacher collaboration and collegiality as workplace conditions. A review. Zeitschrift für Pädagogik, 52(2), 220-237

Klein, E. D., \& Bremm, N. (2019). „It's almost as if I treat the teachers as I want them to treat the students“. Caring als Facette von Führung an Schulen in sozial deprivierter Lage ["It's almost as if I treat the teachers as I want them to treat the students" - Caring as one element of leadership in schools serving disadvantaged communities]. Zeitschrift für Bildungsforschung, 9(1), 89-108. https://doi. org/10.1007/s35834-019-00233-7

Klein, E. D., Young, M. D., \& Böse, S. (2021). Successful leadership in schools serving disadvantaged communities in Germany and the USA. In A. Wilmers, \& S. Jornitz (Eds.), International perspectives on school settings, education policy and digital strategies. A transatlantic discourse in education research (pp. 47-61). Verlag Barbara Budrich

Kuckartz, U. (2018). Qualitative Inhaltsanalyse. Methoden, Praxis, Computerunterstützung [Qualitative content analysis. Methods, practice, and technical solutions]. Beltz Juventa

Lee, E., Neumann, M., Boese, S., \& Maaz, K. (2021). Implementation processes of site-based management at schools in challenging circumstances in Germany: Principals' and teachers' perceptions of openness and consensus in target setting processes. Studies in Educational Evaluation, 70, 1-9. https://doi.org/10.1016/j.stueduc.2021.101003

Leithwood, K., \& Jantzi, D. (2005). A review of transformational school leadership research 1996-2005. Leadership and Policy in Schools, 4(3), 177-199. https://doi.org/10.1080/15700760500244769 
Leithwood, K., Sun, J., \& Schumaker, R. (2019). How school leadership influences student learning: A test of "The Four Paths Model”. Educational Administration Quarterly, 56, 1-30. https://doi.org/10 $.1177 / 0013161 X 19878772$

Leonard, J., \& Leonard, P. E. (1999). Reculturing for collaboration and leadership. The Journal of Educational Research, 92(4), 237-242. https://doi.org/10.1080/00220679909597601

Longhurst, R. (2003). Semi-structured interviews and focus groups. In N. J. Clifford, \& G. Valentine (Eds.), Key methods in geography (pp. 117-132). London: Sage

Marks, H., \& Seashore Louis, K. (1999). Teacher empowerment and the capacity for organizational learning. Educational Administration Quarterly, 35, 707-750. https://doi.org/10.1177/00131 $61 X 99355003$

Mayring, P. (2003). Qualitative Inhaltsanalyse. Grundlagen und Techniken [Qualitative content analysis. Basics and techniques]. Beltz

Meyer, A., Richter, D., \& Hartung-Beck, V. (2020). The relationship between principal leadership and teacher collaboration: Investigating the mediating effect of teachers' collective efficacy. Educational Management Administration \& Leadership. Online first. https://doi.org/10.1177/1741143220945698

Morris, J. E., Lummis, G. W., Lock, G., Ferguson, C., Hill, S., \& Nykiel, A. (2020). The role of leadership in establishing a positive staff culture in a secondary school. Educational Management Administration \& Leadership, 48(5), 802-820. https://doi.org/10.1177/1741143219864937

Muckenthaler, M., Tillmann, T., Weiß, S., \& Kiel, E. (2020). Teacher collaboration as a core objective of school development. School Effectiveness and School Improvement, 31, 1-19. https://doi.org/10.10 $80 / 09243453.2020 .1747501$

Muslic, B., Gisske, A., \& Hartung-Beck, V. (2020). Die qualitative Inhaltsanalyse innerhalb der empirischen Bildungsforschung. Einsatzmöglichkeiten in einer sekundäranalytischen Längsschnittstudie zur Identifikation von Reorganisationsmustern schulischer Organisationen [Qualitative Content Analysis Within Empirical Educational Research: Possible Applications in a Secondary Longitudinal Study for the Identification of Reorganization Patterns of School Organizations]. Forum Qualitative Sozialforschung [Forum: Qualitative Social Research], 21(1). https://doi.org/10.17169/fqs-21.1.3451

Nguyen, D., \& Ng, D. (2020). Teacher collaboration for change: Sharing, improving, and spreading. Professional Development in Education, 46(4), 638-651. https://doi.org/10.1080/19415257.2020.1787 206

Palumbo, R., \& Manna, R. (2019). Making educational organizations able to change: A literature review. International Journal of Educational Management, 33(4), 734-752. https:/doi.org/10.1108/ IJEM-02-2018-0051

Rikkerink, M., Verbeeten, H., Simons, P. R. J., \& Ritzen, H. (2015). A new model of educational innovation: Exploring the nexus of organizational learning, distributed leadership, and digital technologies. Journal of Educational Change, 17. https://doi.org/10.1007/s10833-015-9253-5

Schechter, C. (2008). Organizational learning mechanisms: The meaning, measure, and implications for school improvement. Educational Administration Quarterly, 44(2), 155-186. https://doi.org/10.117 7/0013161X07312189

Seashore Louis, K., \& Lee, M. (2016). Teachers' capacity for organizational learning: The effects of school culture and context. School Effectiveness and School Improvement, 27(4), 534-556. https://doi.org/1 $0.1080 / 09243453.2016 .1189437$

Seashore Louis, K., \& Murphy, J. (2017). Trust, caring and organizational learning: The leader's role. Journal of Educational Administration, 55, 103-126. https://doi.org/10.1108/JEA-07-2016-0077

Silins, H. C., \& Mulford, B. (2004). Schools as learning organisations-Eeffects on teacher leadership and student outcomes. School Effectiveness and School Improvement, 15(3-4), 443-466. https://doi.org/ $10.1080 / 09243450512331383272$

Silins, H. C., Mulford, W. R., \& Zarins, S. (2002). Organizational learning and school change. Educational Administration Quarterly, 38(5), 613-642. https://doi.org/10.1177/0013161X02239641

Sun, J., \& Leithwood, K. (2015). Direction-setting school leadership practices: A meta-analytical review of evidence about their influence. School Effectiveness and School Improvement, 26(4), 499-523. https://doi.org/10.1080/09243453.2015.1005106

Szczesiul, S., \& Huizenga, J. (2014). The burden of leadership: Exploring the principal's role in teacher collaboration. Improving Schools, 17, 176-191. https://doi.org/10.1177/1365480214534545

Tahir, L. M., Musah, M. B., Ali, M. F., Abdullah, A. H., \& Hamzah, M. H. (2021). Principals' views on continuing professional development programmes: Evidence from Malaysia. Educational Management Administration \& Leadership, 1-41. https://doi.org/10.1177/1741143221988953 
Thurlow, A., \& Mills, J. (2014). Telling tales out of school: Sensemaking and narratives of legitimacy in an organizational change process. Scandinavian Journal of Management, 31, 246-254. https://doi. org/10.1016/j.scaman.2014.10.002

Truijen, K. J. P., Sleegers, P., Meelissen, M., \& Nieuwenhuis, A. F. M. (2013). What makes teacher teams in a vocational education context effective? A qualitative study of managers' view on team working. The Journal of Workplace Learning, 25(1), 58-73. https://doi.org/10.1108/13665621311288485

van Dyck, C., Frese, M., Baer, M., \& Sonnentag, S. (2005). Organizational error management culture and its impact on performance: A two study replication. Journal of Applied Psychology, 90(6), 12281240. https://doi.org/10.1037/0021-9010.90.6.1228

Vangrieken, K., Dochy, F., Raes, E., \& Kyndt, E. (2015). Teacher collaboration: A systematic review. Educational Research Review, 15, 17-40. https://doi.org/10.1016/j.edurev.2015.04.002

Voelkel, R. H., \& Chrispeels, J. H. (2017). Understanding the link between professional learning communities and teacher collective efficacy. School Effectiveness and School Improvement, 28(4), 505-526. https://doi.org/10.1080/09243453.2017.1299015

Weick, K. (1995). Sensemaking in organizations. Sage

Wigfield, A., \& Cambria, J. (2010). Expectancy-value theory: Retrospective and prospective. In C. T. Urdan, \& S. A. Karabenick (Eds.), The decade ahead: Theoretical perspectives on motivation and achievement (pp. 35-70). Emerald Group Publishing Limited

Wigfield, A., \& Eccles, J. S. (2000). Expectancy-value theory of achievement motivation. Contemporary Educational Psychology, 25(1), 68-81. https://doi.org/10.1006/ceps.1999.1015

Wirtz, M., \& Caspar, F. (2002). Beurteilerübereinstimmung und Beurteilerreliabilität: Methoden zur Bestimmung und Verbesserung der Zuverlässigkeit von Einschätzungen mittels Kategoriensystemen und Ratingskalen [Inter-rater agreement and inter-rater reliabilty: Methods for determining and improving the reliability of ratings using coding schemes and rating scales]. Hogrefe

Yin, R. K. (2014). Case study research design and methods. Sage

Publisher's note Springer Nature remains neutral with regard to jurisdictional claims in published maps and institutional affiliations.

André Meyer is a research associate and doctoral student in educational sciences at the University of Potsdam, Germany. His research focuses on principal leadership, school improvement, and teacher collaboration.

Viola Hartung-Beck is a professor of empirical research methods, particularly qualitative methods, at the University of Applied Sciences Dortmund, Germany. She is a former research associate at the Institute for Educational Research in the School of Education, University of Wuppertal, where she also received her $\mathrm{PhD}$. Her current research focuses on data-based school improvement processes as the basis for a longterm reorganization of individual schools.

Anna Gronostaj is a project manager at Robert Bosch Stiftung GmbH. She received her PhD from the University of Kassel, Germany, and is a former research associate at the University of Potsdam, Germany. Her research interests are in principal leadership, school improvement, and teacher education.

Sophie Krüger is a former student assistant at the University of Potsdam. She is interested in school improvement and organizational change.

Dirk Richter is a professor of educational research in educational sciences at the University of Potsdam, Germany. He is a former research associate at the Institute for Educational Quality Improvement, Berlin, and Max Planck Institute for Human Development, Berlin, and received his PhD from the Free University, Berlin. His research interests are in the acquisition of professional competencies in teacher training and professional development as well as teacher collaboration. 